\title{
THE EFFECT OF COMPUTER SUPPORTED COLLABORATIVE LEARNING (CSCL) ASSISTED WITH E-LEARNING MEDIA ON STUDENTS' CREATIVITY IN SIMULATION AND DIGITAL COMMUNICATION
}

\author{
Fadil Firdian $^{1, *}$ and Liranti Rahmelina ${ }^{2}$ \\ ${ }^{1,}$ STMIK Indonesia Padang, Jl. Khatib Sulaiman Kel No.1, Lolong Belanti, Padang Utara, Kota Padang,Sumatera Barat \\ 25173, Indonesia \\ E-mail: fadifirdian@ @stmikindonesia.ac.id * \\ *Corresponding Author
}

\begin{abstract}
Previous studies have suggested that Computer Supported Collaborative Learning (CSCL) learning is effectively applied in education. However, prior research has only focused on the impact of CSCL on learning achievement and has not examined students' creativity in the learning process. This study aims to examine the CSCL assisted with e-learning media to increase students' creativity. This study was a quantitative study with a quasi-experimental method. The research design was a pretest-posttest control group design. The validity was determined using content validity, and two experts confirmed that the instrument was acceptable. The normality and homogeneity tests were used in the prerequisite test while a t-test was used to test hypotheses. The findings reported that: (1) after learning with the CSCL assisted with e-learning media, $18.75 \%$ of students were categorized as very creative, $43.75 \%$ of students were creative, and $37.5 \%$ of students were in the acceptable category (3) the CSCL model assisted with e-learning media impact positively to the students' creativity based on the results of the t-test proved by $\mathrm{t}$ count was higher than $\mathrm{t}$ table, namely $6.112>2.04$, with a smaller significant value of $0.05(\mathrm{p}=0.00<0.05)$. Furthermore, the results showed the gain score from four indicators of creativity was 0.655 with moderate interpretation where the highest skill was fluent thinking. As a result, students were creative in executing product design concepts after implementing the CSCL assisted with elearning media.
\end{abstract}

Keywords: computer supported collaborative learning, creativity, e-learning

\section{INTRODUCTION}

Education is a factor that determines human welfare so that it can be used as an indicator of the progress of a nation and country [1]. Improving the quality of education is carried out in stages in various components, one of which is the annual education reference, namely the curriculum [2]. Problems in the world of education always arise with the development and improvement of the abilities of students, the existing environmental situations and conditions, the influence of information and culture, as well as the development of science and technology [3]. The factor of achieving educational goals through the learning process, namely the teacher following the changing times, today's developments have followed the era of technology as a form of student creativity.
Learning that is directed at technology can present student-centered learning which is a student-centered learning approach [4].

The education program in the 4.0 revolution era demands students to be active in the learning process. Only through the involvement or activeness of students in the learning process, they can develop their potential and creativity in learning [5]. SMK (Vocational High School) 2 Padang has a Software Engineering major, in which there are Simulation and Digital Communication subjects. Simulation and digital communication subjects are productive subjects that have several competencies according to the school curriculum. Simulation and digital communication are a tool, not a goal because a lot of tool-using skills are provided for students in this subject [6]. In this learning, students should produce creativity in the form of diverse 
works even though they use several tools, communicating ideas requires tools such as video presentation materials that contain how to unite ideas and concepts through video, and create animation. The process of making a video presentation starts from finding ideas, making a synopsis, making a script, taking pictures, and editing pictures. This process is called the pre-production, production, and postproduction processes [6].

The results of observations on teachers of simulation and digital communication subjects IN class X RPL at Vocational High School N 2 Padang, at the percentage of video and animation making, teachers' teaching methods were less diversified, they used very little media, and they only explained through power points. Interviews with students, on the other hand, demonstrated that they had difficulties comprehending video presentation material and creating animation without visualizing the material and simulations. Based on the problems, an effective learning approach and media are required to act as an intermediary in expressing ideas, solutions, and communication to achieve expected products.

\section{CSCL (Computer Supported}

Collaborative Learning) is consistency between learning design plans and activities by collaborating learning activities, which focuses on supporting an effective learning process [7]. The CSCL learning model embodies a combination model of cooperative learning and the use of computers and the internet as media in learning[8]. Collaboration is one of the most successful learning models of the twenty-first century [9]. There is research that reveals computer-supported collaborative learning (CSCL) with social network awareness (SNA) mechanisms has been widely adopted because it can increase the effectiveness of online collaborative learning [10].

The implementation of CSCL resulted in educational changes, especially when Covid 19 required learning to be at home. Previously conventional learning was conducted without demonstration of how to make animation and students are not allowed to train themselves. With this model, students collaborate by emphasizing intensive group collaboration in the media provided. It is expected that the students can increase their active involvement in creating products as a form of creativity in the learning process. When comparing the utilization of CSCL to traditional learning models, the increase in creativity was demonstrated.

Learning media serves as an intermediary in overcoming student incomprehension in the materials taught by the teacher through the application of collaborative learning practices in groups [11]. The CSCL paradigm has to be carefully evaluated to see if it increases students' creativity in turning ideas into works by allowing students to engage with other students via e-learning media [12]. This elearning plays an active role in improving student learning and progress in the Industrial Revolution Era 4.0 [13]. This e-learning application includes strategic and practical applications in the learning process [14]. In developed countries, e-learning is very much needed because most of the resources have been invested in the education sector [15]. Face-toface education is now higher, because of the awareness of students and for the school to reduce the cost of physical classrooms [16]. It is important to understand the main features of online learning to create high-quality learning [17].

This platform provides collaborative learning where students can build their abilities to achieve learning goals supported by technological media. Effective usage of elearning can also help students become more motivated to learn [18]. This activity is monitored by the teacher. The teacher can watch, communicate, and teach visually using this e-learning media, so that students studying simulation and digital communication can produce creative work.

Previous research showed that Computer Supported Collaborative Learning (CSCL) learning has been widely used in education, 
particularly online learning [19]-[23]. However, previous research has only explored the influence of CSCL on learning achievement. There is still limited research on how students use creativity in CSCL classrooms. This study aims to test the CSCL assisted with e-learning media to increase students' creativity.

\section{METHOD}

This is a quasi-experimental study that used a quantitative approach. The research design was a control group pretest-posttest design adopted from Sugiyono [24] as presented in Table 1. The research procedure is illustrated in Figure 1.

Table 1. Pretest-Posttest Control Group Design

\begin{tabular}{cccc}
\hline Group & Pretest & Treatment & Posttest \\
\hline $\begin{array}{c}\text { Experiment } \\
\text { Control }\end{array}$ & $\mathrm{O}_{1}$ & $\begin{array}{c}\text { Y (The e- } \\
\text { learning-assisted } \\
\text { CSCL approach) }\end{array}$ & $\mathrm{O}_{2}$ \\
$\mathrm{O}_{4}$
\end{tabular}

Information :

$\mathrm{O}_{1}=$ Pretest mean of the experimental group

$\mathrm{O}_{2}=$ The posttest mean of the experimental group

$\mathrm{O}_{3}=$ Pretest mean of the control group

$\mathrm{O}_{4}=$ The posttest mean of the control group

$\mathrm{Y}=$ The treatment with the CSCL approach uses elearning

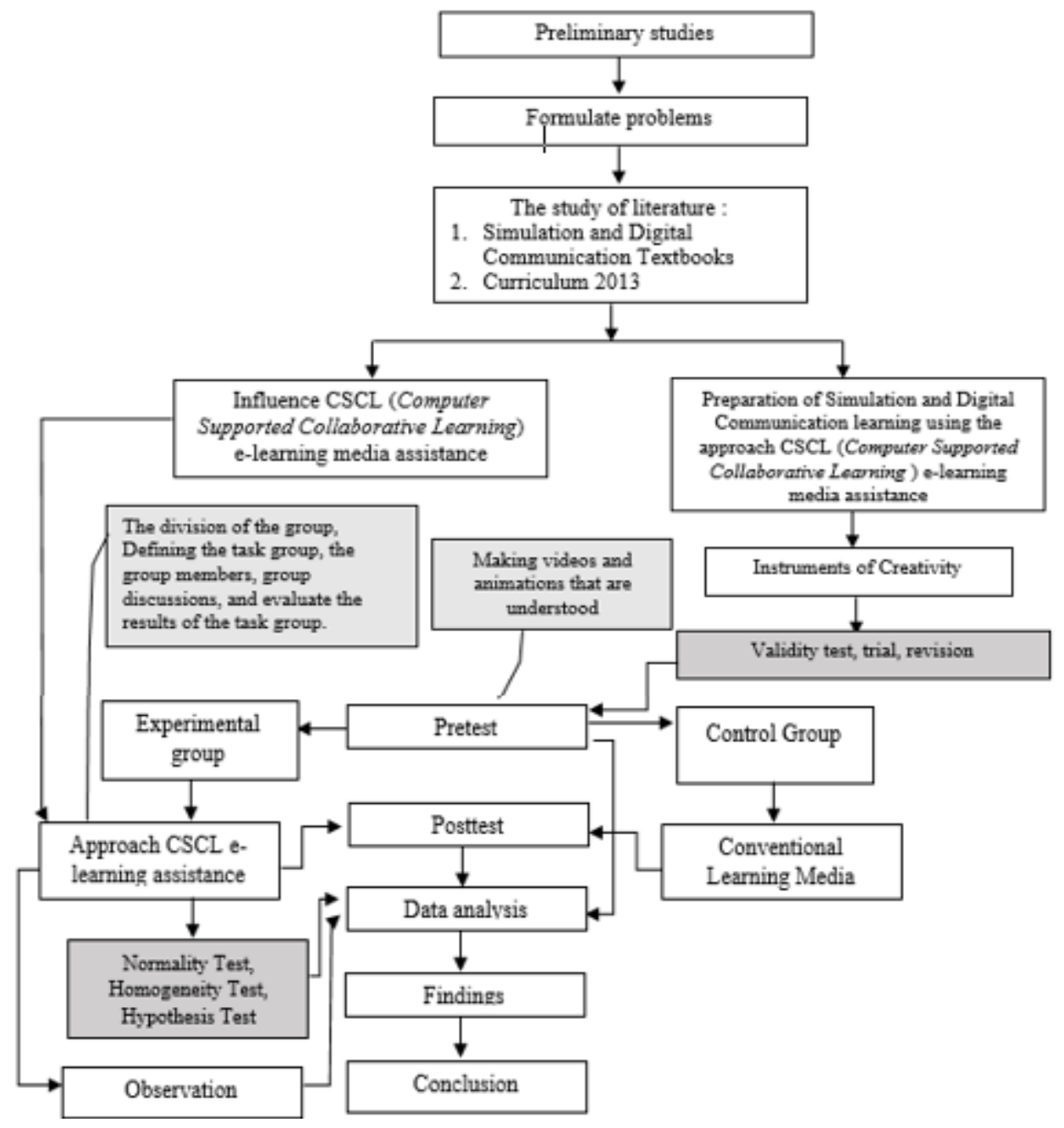

Figure 1. Research procedure

Data collection was conducted with psychomotor tests (performance). This technique was used to determine the level of creativity of students, namely the ability of students to increase creativity in making videos and animation. The test was carried out by 
pretest and posttest. The pretest was given to both groups to determine the students' initial abilities before the treatment. The posttest aims to compare the final results of creativity in making videos and animations by comparing the effects of making videos and animations between classes whose learning models use CSCL assisted by e-learning media and those without using CSCL learning models assisted by e-learning media.

This study applied a normality test, homogeneity test dan hypothesis testing. This test was used to test normal data, the same variance, and the effect of the learning model on student creativity. This study also used a comparative analysis of the creativity of the experimental class and the control class through the gain score formula as follows [25]. The levels of the gain score are categorized into three categories in Table 2.

$<\mathrm{g} \geq=\frac{S f-S i}{100-S i}$

$<g>\quad=$ normalized gain score

Sf $\quad=$ posttest score

$\mathrm{Si} \quad=$ pretest score

$100=$ maximum score

Table 2. Gain Score Rate

\begin{tabular}{cc}
\hline Normalized Gain Score & Interpretation \\
\hline $\mathrm{g}>0.7$ & High \\
$0.3<\mathrm{g} \leq 0.7$ & Medium \\
$\mathrm{G} \leq 0.3$ & Low \\
\hline
\end{tabular}

This study examined CSCL learning assisted by e-learning media in increasing students' creativity in making videos and animations compared with classes with conventional learning. Comparisons between the experimental and control classes were used to calculate the increase in student creativity.

\section{RESULTS AND DISCUSSION}

The validity testing of the instrument based on the experts' evaluation is presented in Table 3. It was concluded that the creativity instrument was suitable for use in data collection. Table 4 describes the instruments that consisted of indicators of creativity, among others, fluent thinking, flexibility, originality, and elaboration.

Table 3. The Validity of the Instrument

\begin{tabular}{lcc}
\hline \multicolumn{1}{c}{ Quality } & Score Interval & Number of experts \\
\hline feasible & $6 \leq$ score $\leq 10$ & 2 \\
not feasible & $0 \leq$ score $\leq 5$ & 0 \\
\hline
\end{tabular}

Table 4. The Indicators of the Instrument

\begin{tabular}{|c|c|c|c|}
\hline No & Indicator & Sub Indicator & $\begin{array}{c}\text { No } \\
\text { question }\end{array}$ \\
\hline 1 & $\begin{array}{l}\text { Fluent } \\
\text { thinking } \\
\text { skills }\end{array}$ & $\begin{array}{l}\text { - Views apply design } \\
\text { elements } \\
\text { - Views apply design } \\
\text { principles } \\
\text { - Views apply parts of } \\
\text { the video and } \\
\text { animation } \\
\text { - Display using } \\
\text { learning resources }\end{array}$ & $1,2,3,4$ \\
\hline 2 & $\begin{array}{l}\text { Flexible } \\
\text { thinking } \\
\text { skills }\end{array}$ & $\begin{array}{l}\text { - Display with } \\
\text { flexible proportions } \\
\text { between finding } \\
\text { ideas, making a } \\
\text { synopsis, making a } \\
\text { script, taking } \\
\text { pictures, and editing } \\
\text { pictures } \\
\text { - The resulting design } \\
\text { effect is in } \\
\text { accordance with the } \\
\text { character of the } \\
\text { object } \\
\text { - The presentation } \\
\text { technique is correct } \\
\text { and complete }\end{array}$ & $5,6,7$ \\
\hline 3 & $\begin{array}{l}\text { Original } \\
\text { thinking } \\
\text { skills }\end{array}$ & $\begin{array}{l}\text { - The design shown is } \\
\text { different from other } \\
\text { students } \\
\text { - Its appearance is } \\
\text { following the video } \\
\text { and animation } \\
\text { design, placement } \\
\text { according to } \\
\text { function. }\end{array}$ & 8,9 \\
\hline 4 & $\begin{array}{l}\text { Elaborating } \\
\text { skills }\end{array}$ & $\begin{array}{l}\text { - Views created with } \\
\text { a combination of } \\
\text { effects and colors } \\
\text { - Display detailed and } \\
\text { clear using e- } \\
\text { learning } \\
\text { - Enrich the details of } \\
\text { display videos and } \\
\text { animations by using } \\
\text { e-learning }\end{array}$ & $10,11,12$ \\
\hline
\end{tabular}

The pretest is a test of the level of students' knowledge of the presented materials. 
The pretest was conducted in 2 classes, namely the experimental class and the control class. The subjects of the experimental class pretest consisted of 16 students. The results of the creativity pretest of creating videos and animations in the experimental class had the lowest score of 20.00 and the highest score of 68.00. The mean, median, and standard deviation scores achieved were 39.4, 33.5, and 16.47 respectively. The distribution of the pretest category in the experimental class is presented in Table 5.

Table 5. Distribution of Experimental Class Pretest Categories

\begin{tabular}{ccccc}
\hline No & Score & Frequency & $\begin{array}{c}\text { Percentage } \\
\%\end{array}$ & Category \\
\hline 1 & 85 to 100 & 0 & 0 & Very good \\
2 & 69 to 84 & 0 & 0 & Good \\
3 & 53 to 68 & 4 & 25 & Acceptable \\
4 & 37 to 52 & 3 & 18.75 & Poor \\
5 & 0 to 36 & 9 & 56.25 & Very Poor \\
& Total & 16 & 100 & \\
\hline
\end{tabular}

Table 5 shows that based on the pretest results, 4 students $(25 \%)$ were in the acceptable category, 3 students $(18.75 \%)$ were in the poor category, 9 students $(56.25 \%)$ are in the very poor category. None of the students were in the very good and good categories. The number of students categorized as very poor was $56.25 \%$. This indicated that the students need learning resources to overcome the problem.

The subjects of the control class pretest were 16 students. The results of the creativity pretest of creating videos and animations in the control class had the lowest score of 25.00 and the highest score of 67.67. The mean, median, standard deviation achieved by the control class were $42.25,41.5$, and 13.57 respectively. Table 6 represents the distribution of the pretest category in the control class. Five students $(31.25 \%)$ were in the acceptable category, 5 students $(31.25 \%)$ in the poor category, 6 students $(37.5 \%)$ in the very poor category, and none of the students were in the very good and good categories. This indicated that the learning process was not able to optimize the learning outcomes. $\underline{\text { Table 6. Distribution of Control Class Pretest Categories }}$

\begin{tabular}{cclcl}
\hline No & Score & Frequency & $\begin{array}{c}\text { Percentage } \\
\%\end{array}$ & Category \\
\hline 1 & 85 to 100 & 0 & 0 & Very good \\
2 & 69 to 84 & 0 & 0 & Good \\
3 & 53 to 68 & 5 & 31.25 & Acceptable \\
4 & 37 to 52 & 5 & 31.25 & Poor \\
5 & 0 to 36 & 6 & 37.5 & Very Poor \\
& Total & 16 & 100 & \\
\hline
\end{tabular}

After the implementation of treatment, the posttest was carried out in the experimental class and the control class. This posttest was used to evaluate whether or not the goal of increasing creativity in video and animation production has been accomplished. There were 16 posttest subjects in the experimental class. It was obtained the lowest score of 56.00 and the highest score of 89.00. The mean, median, and standard deviation scores of the posttest in the experimental class were $73.00,73.5$ and the and 11.57 respectively. The distribution of experimental class posttest categories can be seen in Table 7.

Table 7. Distribution of Experimental Class Posttest

\begin{tabular}{ccccl}
\hline \multicolumn{5}{c}{ Categories } \\
No & Score & Frequency & $\begin{array}{c}\text { Percentage } \\
\%\end{array}$ & Category \\
\hline 1 & 85 to 100 & 3 & 18.75 & Very good \\
2 & 69 to 84 & 7 & 43.75 & Good \\
3 & 53 to 68 & 6 & 37.5 & Acceptable \\
4 & 37 to 52 & 0 & 0 & Poor \\
5 & 0 to 36 & 0 & 0 & Very Poor \\
& Total & 16 & 100 & \\
\hline
\end{tabular}

Three students $(18.75 \%)$ were in the very good category, 7 students $(43.75 \%)$ were in a good category, 6 students $(37.5 \%)$ were in the acceptable category. Students can develop their creativity in generating movies and animations by using the instructional resources, which contain attractive visualizations and easy-tounderstand material.

Table 8 demonstrates the score of creativity from the posttest. Because the four indications have an average of 73.00, the skills acquired after conducting learning using the CSCL helped by e-learning have a high score, indicating that the students are actively engaged in the learning process. 
Tabel 8. The Score of Creativity from the Posttest

\begin{tabular}{clc}
\hline No & Indicator of Creativity & $\begin{array}{c}\text { The Average } \\
\text { Score }\end{array}$ \\
\hline 1 & Fluent thinking skills & 79.53 \\
2 & Flexible thinking skills & 71.64 \\
3 & Original thinking skills & 68.28 \\
4 & Elaborating skills & 68.68 \\
\hline
\end{tabular}

The subjects of the posttest control class were 16 people. The posttest in the control class obtained the lowest score of 25.00 and the highest score of 68.00. The mean, median and standard deviations score achieved by the control class in the posttest were 45.12, 45.00, and 13.79 respectively. Table 9 describes the distribution of control class posttest categories. Five students $(31.25 \%)$ were classified as very poor, five students $(31.25 \%)$ as poor, and six students (37.5\%) as acceptable. This revealed that traditional classroom approaches and media had failed to improve students' creativity in creating videos and animations.

An examination was carried out to determine the control class's creativity score. Table 10 explains the findings. Because the four indicators have an average of 45.13, the resulting skills following conventional learning have a low score, indicating that students are less active in learning.
Before testing the hypothesis, the first steps in data analysis were the normality test and homogeneity test. The normality test used the Kolmogorov Smirnov test. This test served to determine the sample distribution pattern of the data obtained from the pretest and posttest [26].

The normality test calculated the values that have been generated by students, then analysis was carried out to determine whether the research data was normal or not. Table 11 presents the calculation result of all variables.

\begin{tabular}{ccccl}
\multicolumn{6}{c}{ Table } & 9. Distribution of Control Class Posttest Categories \\
\hline No & Score & Frequency & $\begin{array}{c}\text { Percentage } \\
\%\end{array}$ & Category \\
\hline 1 & 85 to 100 & 3 & 18.75 & Very good \\
2 & 69 to 84 & 7 & 43.75 & Good \\
3 & 53 to 68 & 6 & 37.5 & Acceptable \\
4 & 37 to 52 & 0 & 0 & Poor \\
5 & 0 to 36 & 0 & 0 & Very Poor \\
& Total & 16 & 100 & \\
\hline
\end{tabular}

Tabel 10. The Value of Creativity from the Mean Score of the Pretest

\begin{tabular}{clc}
\hline & & \\
No & \multicolumn{1}{c}{ Indicator of Creativity } & $\begin{array}{c}\text { The average } \\
\text { score }\end{array}$ \\
\hline 1 & Fluent thinking skills & 45.98 \\
2 & Flexible thinking skills & 44.17 \\
3 & Original thinking skills & 46.12 \\
4 & Elaborating skills & 44.27 \\
\hline
\end{tabular}

Table 11. Normality Test Results

\begin{tabular}{lcccccc}
\hline & \multicolumn{3}{c}{ Kolmogorov-Smirnov $^{\mathrm{a}}$} & \multicolumn{3}{c}{ Shapiro-Wilk } \\
& Statistic & Df & Sig. & Statistic & Df & Sig. \\
\hline PretestEks & .175 & 16 & $.200^{*}$ & .907 & 16 & .103 \\
PosttestEks & .165 & 16 & $.200^{*}$ & .925 & 16 & .206 \\
PretestKtrl & .135 & 16 & $.200^{*}$ & .923 & 16 & .187 \\
PosttestKtrl & .176 & 16 & $.200^{*}$ & .929 & 16 & .236 \\
\hline
\end{tabular}

*. This is a lower bound of the true significance.

a. Lilliefors Significance Correction

The results of normality testing indicated that the data in this study were normally distributed because the significance value was greater than $0.05(\mathrm{p}>0.05)$. Thus, the data has fulfilled the requirements analysis. The homogeneity test was performed once the normality test was completed. The variance in the score results was homogeneous. Table 12 summarizes the findings of the homogeneity test. The pretest and posttest significance scores have a score of $0.593>0.05$ meaning that the data has the same variance.

Table 12. Results of the Homogeneity Test

\begin{tabular}{cccc}
\hline \multicolumn{4}{c}{ Test of Homogeneity of Variances } \\
Posttest \\
\hline Levene Statistic & df1 & df2 & Sig. \\
\hline .291 & 1 & 30 & .593 \\
\hline
\end{tabular}

The hypothesis in this study includes the influence of CSCL learning assisted by e- 
learning media on students' creativity in simulation and digital communication. To discover significant differences between the pretest and posttest, a sample t-test was used [[27]. In Table 13, the results of the analysis using the t-test are presented.

Table 13. SPSS Hypothesis Test Results

\begin{tabular}{|c|c|c|c|c|c|c|c|c|c|}
\hline & & \multicolumn{5}{|c|}{$\begin{array}{l}\text { Paired Samples Test } \\
\text { Paired Differences }\end{array}$} & \multirow{3}{*}{$\mathrm{t}$} & \multirow{3}{*}{$\mathrm{df}$} & \multirow{3}{*}{$\begin{array}{c}\text { Sig. } \\
(2- \\
\text { tailed) }\end{array}$} \\
\hline & & \multirow[t]{2}{*}{ Mean } & \multirow{2}{*}{$\begin{array}{c}\text { Std. } \\
\text { Deviation }\end{array}$} & \multirow{2}{*}{$\begin{array}{l}\text { Std. Error } \\
\text { Mean }\end{array}$} & \multicolumn{2}{|c|}{$\begin{array}{l}95 \% \text { Confidence Interval of } \\
\text { the Difference }\end{array}$} & & & \\
\hline & & & & & Lower & Upper & & & \\
\hline Pair 1 & $\begin{array}{l}\text { Experiment - } \\
\text { Control }\end{array}$ & 27.87500 & 18.24235 & 4.56059 & 18.15434 & 37.59566 & 6.112 & 15 & .000 \\
\hline
\end{tabular}

From the Table 13, it can be seen that the significance value is smaller than $0.05(\mathrm{p}=0.00$ $<0.05)$ or $t$ count $>t$ table $(6.112>2.04)$. The value indicates that there was the effect of CSCL learning assisted by e-learning media on students' creativity in making video and animation thus the hypothesis is accepted. Furthermore, the difference in creativity can be noticed by the acquisition of a gain score from the creativity instrument according to Table 14 based on the gain score test.

Table 14. Gain Score Result

\begin{tabular}{|c|c|c|c|c|c|}
\hline \multirow{2}{*}{ No } & \multirow{2}{*}{$\begin{array}{l}\text { Indicator of } \\
\text { Creativity } \\
\text { Instruments }\end{array}$} & \multicolumn{4}{|c|}{ Gain score } \\
\hline & & Exp & $<\mathrm{g}>$ & $\mathrm{Ctrl}$ & $<\mathrm{g}>$ \\
\hline 1 & $\begin{array}{l}\text { Fluent } \\
\text { thinking } \\
\text { skills }\end{array}$ & 0.655 & Medium & 0.049 & Low \\
\hline 2 & $\begin{array}{l}\text { Flexible } \\
\text { thinking } \\
\text { skills }\end{array}$ & 0.540 & Medium & 0.029 & Low \\
\hline 3 & $\begin{array}{l}\text { Original } \\
\text { thinking } \\
\text { skills }\end{array}$ & 0.474 & Medium & 0.082 & Low \\
\hline 4 & $\begin{array}{l}\text { Elaborating } \\
\text { skills }\end{array}$ & 0.488 & Medium & 0.049 & Low \\
\hline
\end{tabular}

The results indicated the average acquisition of the experimental class was higher than the control class. The results of the gain score of creativity in the experimental class and the control class, show the comparison of learning using the CSCL model with conventional learning.

This could be seen in the experimental class, none of the pretest results were very good. After the treatment, the posttest showed that 3 students scored very well with a score range of 85 to 100 , and the mean score of creativity was also categorized as high. This occurred as a result of the teacher dividing groups and giving discussion forums in the elearning media, as well as the teacher demonstrating the basic method of creating animations and videos based on the curriculum so that each group actively communicates product ideas. In this learning model, students learn through collaboration between teachers and students, students in groups with e-learning assistance, and aspire to ideas to produce products, this product will show the level of student creativity.

Purnamawati [28] also reported similar results by using a combination of cooperative learning model learning and the use of computers and the internet as learning media. The use of this learning media facilitates teachers and students to share information and interact either personally or in groups or in general. Students are directed to be active in reconciling ideas and embodiment of products, for teachers to assess the results of the product by looking at the level of creativity of the products produced. Whereas in traditional learning, students simply watch without practice since no media is provided, simulation learning and digital communication are limited to student visuals, and students have few opportunities to explore their potential [29].

\section{CONCLUSION}

This study reported an increase of students' creativity of vocational high school students in SMK N 2 Padang in making videos 
and animations through the use of CSCL learning assisted by e-learning media. Students' creativity after implementing CSCL learning assisted by e-learning media had a mean score of 73.00 categorized as creative. The effect was evidenced by a significance score which was smaller than $0.05(\mathrm{p}=0.00<0.05)$ or $\mathrm{t}$ count $>\mathrm{t}$ table $(6.112>2.04)$. This suggests that CSCL learning assisted with e-learning media has an impact on students' creativity in making videos and animations. The students' creativity was evaluated based on four indicators of creativity in the experimental class. The highest indicator was fluent thinking with a score of 0.655 thus it was concluded that after implementing learning using the CSCL model, creative students developed the product design idea. This also proves that this model can be used in other subjects.

\section{ACKNOWLEDGEMENTS}

This study was supported by KEMENRISTEKDIKTI with contract number: 068/LL10/PG/2020.

\section{REFERENCES}

[1] Y. E. Saputri, I. Ismail, and S. Mulyani, "Meningkatkan motivasi belajar simulasi digital melalui pemanfaatan edmodo pada siswa sekolah menengah kejuruan," J. Komun. Pendidik., vol. 2, no. 2, p. 132, 2018, doi: 10.32585/jkp.v2i2.126.

[2] F. Firdian and I. T. Maulana, "Development of interactive multimedia learning media in software application courses," J. Pendidikan, Teor. , Penelit. dan Pengemb., vol. Vol 3 No.6, pp. 822-828, 2018.

[3] A. Rifai and S. Chendra Wibawa, "Pengembangan modul simulasi dan komunikasi digital berdasarkan model pembelajaran numbered heads together (NHT) kelas x RPL SMK Negeri 2 Surabaya," It-Edu, vol. 3, no. 01, 2018.
[4] L. Rahmelina, F. Firdian, I. T. Maulana, H. Aisyah, and J. Na'am, "The effectiveness of flipped classroom model using the e-learning media in introduction to information technology course," Int. J. Emerg. Technol. Learn., vol. 14, no. 21, pp. 148-162, 2019, doi: https://doi.org/10.3991/ijxx.vx.ix.xxxx.

[5] Kenedi, "Pengembangan kreativitas siswa dalam proses pembelajaran di kelas II SMP Negeri 3 Rokan IV Koto," J. Ilmu Pendidik. Sos. sains, dan Hum., vol. 3, no. 2, pp. 329-348, 2017.

[6] R. S. Indahini, Sulton, and A. Husna, "Pengembangan multimedia," Teknol. Pendidik., vol. 1, no. 2, pp. 141-148, 2018.

[7] L. Zheng, P. Cui, and X. Zhang, "Does collaborative learning design align with enactment? An innovative method of evaluating the alignment in the CSCL context," Int. J. Comput. Collab. Learn., vol. 15, no. 2, pp. 193-226, 2020, doi: 10.1007/s11412-020-09320-8.

[8] H. Jaya, S. Haryoko, and L. Lu'mu, "Collaborative learning for children with special needs through computer supported collaborative learning At vocational high schools," $J$. Pendidik. Teknol. dan Kejuru., vol. 23, no. 4, pp. 346-354, 2017, doi: 10.21831/jptk.v23i4.14387.

[9] I. T. Maulana, R. D. Hary, R. Purwasih, F. Firdian, T. A. Sundara, and J. Na'am, "Project-based learning model practicality on local network devices installation subject," Int. J. Emerg. Technol. Learn., vol. 14, no. 15, pp. 94-106, 2019, doi: 10.3991/ijet.v14i15.10305.

[10] J. Lin and H. K. Lin, "User acceptance in a computer-supported collaborative learning (CSCL) environment with social network awareness (SNA) support," Australas. J. Educ. Technol., vol. 35 , no. 1, pp. 100-115, 2019, doi: 10.14742/ajet.3395. 
[11] S. Uttamchandani, A. Bhimdiwala, and C. E. Hmelo-Silver, "Finding a place for equity in CSCL: ambitious learning practices as a lever for sustained educational change," Int. J. Comput. Collab. Learn., no. Star 1989, 2020, doi: 10.1007/s11412-020-09325-3.

[12] A. Muniasamy and A. Alasiry, "Deep learning: The impact on future e learning," Int. J. Emerg. Technol. Learn., vol. 15, no. 1, pp. 188-199, 2020, doi: 10.3991/IJET.V15I01.11435.

[13] S. Tosheva and C. Martinovska, "Adaptive e-learning system in secondary education," Int. J. Emerg. Technol. Learn., vol. 7, no. Special Focus Paper, pp. 36-41, 2012, doi: 10.3991/ijet.v7iS1.1913.

[14] H. Flavell, C. Harris, C. Price, E. Logan, and S. Peterson, "Empowering academics to be adaptive with eLearning technologies: An exploratory case study," Australas. J. Educ. Technol., vol. 35, no. 1, pp. 1-15, 2019.

[15] S. I. Dasuki and N. Yakubu, "Assessing e-learning systems success in Nigeria: An application of the DeLone and McLean information systems success model," J. Inf. Technol. Educ., vol. 17, pp. 182-202, 2018, doi: 10.28945/4077.

[16] D. Kira, F. Nebebe, and R. G. Saadé, "The persistence of anxiety experienced by new generation in online learning," in Proceedings of the Informing Science + Information Technology Education Conferene, 2018, pp. 79-88, doi: 10.28945/4040.

[17] H. Tyagi and S. Malik, "Online teaching in Delhi-NCR schools in India $\mathrm{d}$ uring Covid-19 pandemic," Indian J. Sci. Technol., vol. 13, no. 38, pp. 4036-4054, 2020, doi: 10.17485/IJST/v13i38.1613.

[18] M. Samir Abou El-Seoud, I. A. T. F. Taj-Eddin, N. Seddiek, M. M. ElKhouly, and A. Nosseir, "E-learning and students' motivation: A research study on the effect of e-learning on higher education," Int. J. Emerg. Technol. Learn., vol. 9, no. 4, pp. 20-26, 2014, doi: 10.3991/ijet.v9i4.3465.

[19] C. Phielix, F. J. Prins, and P. A. Kirschner, "Awareness of group performance in a CSCL-environment: Effects of peer feedback and reflection," Comput. Human Behav., vol. 26, no. 2, pp. 151-161, Mar. 2010, doi: 10.1016/J.CHB.2009.10.011.

[20] G. Zurita and M. Nussbaum, "Computer supported collaborative learning using wirelessly interconnected handheld computers," Comput. Educ., vol. 42, no. 3, pp. 289-314, Apr. 2004, doi: 10.1016/J.COMPEDU.2003.08.005.

[21] N. Wahyuningtyas and I. Idris, "Increasing geographic literacy through the development of computer supported collaborative learning," Int. J. Emerg. Technol. Learn., vol. 15, no. 7, pp. 7485, 2020.

[22] S. Alberto Nava Lara and J. A. Canchola González, "Computer supported collaborative learning. A peer-topeer experience at the Ph.D. level," ACM Int. Conf. Proceeding Ser., pp. 322-325, Oct. 2020, doi: $10.1145 / 3434780.3436574$.

[23] O. Birgin and H. Acar, "The effect of computer-supported collaborative learning using GeoGebra software on 11th grade students' mathematics achievement in exponential and logarithmic functions," Int. J. Math. Educ. Sci. Technol., pp. 1-18, 2020, doi: 10.1080/0020739X.2020.1788186.

[24] Sugiyono, Metodelogi Penelitian Pendidikan. Bandung: Alfabeta, 2016.

[25] R. R. Hake, Analyzing Change/Gain Scores, no. Division D. 1999.

[26] R. A. Avianti, "Pengembangan Tes Kreativitas," Jurnal Pendidik. Univ. Negeri, pp. 91-98, 2015.

[27] A. H. Albashtawi and K. B. Al Bataineh, "The effectiveness of google classroom 
among EFL students in Jordan: An innovative teaching and learning online platform," Int. J. Emerg. Technol. Learn., vol. 15, no. 11, pp. 78-88, 2020, doi: 10.3991/IJET.V15I11.12865.

[28] H. J. Purnamawati, "Pengembangan model pembelajaran kolaboratif melalui pendekatan CSCL (computer supported collaborative learning) pada fakultas teknik Universitas Negeri Makassar,"
Media Komun. Pendidik. Teknol. dan Kejuru., vol. 3, no. 21, pp. 167-185, 2016.

[29] D. Kurnia Dwi Ariyanti, "Effect of problem-based learning model and motivation," Pendidik. dan Teknol. dan Kejuru., vol. 24, no. 2, pp. 270-277, 2018, doi: 10.21831/jptk.v24i2.20005. 